\title{
The Financial Industry's Challenge of Developing
}

\section{Commodity Derivatives}

\author{
Joost M.E. Pennings and M.T.G. Meulenberg ${ }^{*}$
}

With a constant new stream of financial services coming to the market, each often more exotic and complicated than the last, the financial services industry, which includes commodity derivatives exchanges, brokerage houses and banks providing price risk reduction services (the so-called hedging services), is one of the fastest growing industries. In order to assure survival, these companies show a rapid product innovation. However, for commodity derivatives the risk of failure is considerable. This paper presents a new and integrative approach towards commodity derivatives management, which makes it easier to gain insight into the viability of new commodity derivatives before introduction, to assess and improve the viability of existing commodity derivatives and to provide the managers of the financial services industry with information about the tools they can use in the product development process of commodity derivatives.

- Joost M.E. Pennings is a visiting research scholar at the Office for Futures and Options Research at the University of Illinois at Urbana-Champaign, a visiting professor at the Wageningen University and Research Centre and director of the Foundation for Research in Agricultural Derivatives. Matthew T.G. is a Professor and Chair in the Department of Marketing and Marketing Research at the Wageningen University. Corresponding author: Joost M.E. Pennings, University of Illinois at Urbana-Champaign, Office for Futures and Options Research, 326 Mumford Hall, MC-710, 1301 W. Gregory Drive, Urbana, IL 61801. Phone: 217-333-8442, Fax: 217-333-5538, Email: jmpennin@uiuc.edu 


\section{The Financial Industry's Challenge of Developing}

\section{Commodity Derivatives}

With a constant new stream of financial services coming to the market, each often more exotic and complicated than the last, the financial services industry, which includes commodity derivatives exchanges, brokerage houses and banks providing price risk reduction services (the so-called hedging services), is one of the fastest growing industries. In order to assure survival, these companies show a rapid product innovation. However, for commodity derivatives the risk of failure is considerable. This paper presents a new and integrative approach towards commodity derivatives management, which makes it easier to gain insight into the viability of new commodity derivatives before introduction, to assess and improve the viability of existing commodity derivatives and to provide the managers of the financial services industry with information about the tools they can use in the product development process of commodity derivatives.

\section{INTRODUCTION}

Trading in derivative contracts has a long history. The first recorded accounts of derivative contracts can be traced back to the philosopher Thales of Miletus in ancient Greece, who, during winter, negotiated what were essentially call options on oil presses for the spring olive harvest. De la Vega reported in 1688 that options and futures, or "time bargains" as they were then known, were trading on the Amsterdam Bourse soon after it was opened. Evidence also suggests those futures contracts for rice was traded in Japan in the 17th and 18th centuries (e.g., Sill, 1997). 
Commodity derivative exchanges are and have been very important institutions in commodity pricing and have been prominent in the United States for over a century. In Europe too, commodity derivatives are booming. Price volatility for raw materials has increased for many reasons including the recent changes within the Common Agricultural Policy of the European Union and the WTO which have increased price risks for both the primary producers and the processing industry as well.

The growth of commodity derivative exchanges has also been stimulated by technological developments. Of increasing importance, in this respect, is the use of automatic computer-guided trading systems. Also, the introduction of the single European currency will give an impulse to commodity derivatives, since exchange rate risk within the European Union will be eliminated, making national commodity derivatives markets more attractive for hedgers and speculators from other EU-countries. All these developments contribute to the renewed interest financial institutions have in commodity derivatives markets. They have led several derivatives exchanges, including the Amsterdam Exchanges, the Chicago Board of Trade, the Chicago Mercantile Exchange, the London International Financial Futures \& Options Exchange and the Marché à Terme International de France, to develop new commodity derivatives (see Table I).

\section{TABLE I}


Volume of Commodity and Financial Futures and Options

U.S. Exchanges (millions of contracts).

\begin{tabular}{lllllllll}
\hline \multicolumn{2}{c}{$\begin{array}{l}\text { Futures } \\
\end{array}$} & Commodities & Financials & Commodities & Financials \\
\hline Year & & & & & & & & \\
1991 & 98.6 & $(37.7 \%)$ & 162.8 & $(62.3 \%)$ & 16.9 & $(28.0 \%)$ & 43.4 & $(72.0 \%)$ \\
1992 & 102.6 & $(35.5 \%)$ & 186.8 & $(64.5 \%)$ & 19.7 & $(28.3 \%)$ & 49.9 & $(71.7 \%)$ \\
1993 & 111.3 & $(34.2 \%)$ & 214.2 & $(65.8 \%)$ & 20.7 & $(26.9 \%)$ & 56.2 & $(73.1 \%)$ \\
1994 & 128.1 & $(31.2 \%)$ & 282.9 & $(68.8 \%)$ & 22.1 & $(22.3 \%)$ & 77.1 & $(77.7 \%)$ \\
1995 & 126.1 & $(30.8 \%)$ & 283.3 & $(69.2 \%)$ & 22.2 & $(23.3 \%)$ & 73.2 & $(76.7 \%)$ \\
1996 & 138.7 & $(35.2 \%)$ & 255.4 & $(64.8 \%)$ & 29.9 & $(29.7 \%)$ & 70.5 & $(70.3 \%)$ \\
1997 & 141.9 & $(34.1 \%)$ & 275.3 & $(65.9 \%)$ & 30.3 & $(28.9 \%)$ & 74.8 & $(71.1 \%)$ \\
\hline
\end{tabular}

Source: CFTC 1998.

Note: Financials derivatives include currencies and commodity derivatives include grains, oilseeds, livestock, metals and energy products. 
In one of the fastest growing industries, with an almost exponential growth over the last decade, competition is stiff (Davey and Maguire, 1996). The derivatives industry is composed of competing firms: exchanges, banks and brokerage houses offering and facilitating over-the-counter trading. Rapid product innovation means survival. With commodity derivatives, the risk of failure is considerable (Miller, 1990). 


\section{TABLE II}

\section{The number of commodity derivatives' introductions and their average annual volume, split according to futures and options, around the world during the period 1994-1998}

$\begin{array}{lcrcr}\text { Exchange } & \text { Futures } & \begin{array}{c}\text { Average } \\ \text { volume }\end{array} & \text { Options } & \begin{array}{r}\text { Average } \\ \text { volume }\end{array} \\ \text { LIFFE } & 8 & 496409 & 7 & 32401 \\ \text { CME } & 7 & 171163 & 7 & 17523 \\ \text { CBOT } & 4 & 34233 & 8 & 5087 \\ \text { CSCE } & 5 & 2918 & 5 & 528 \\ \text { NYMEX } & 4 & 51596 & 6 & 20026 \\ \text { BM\&F } & 5 & 63512 & 5 & 443642 \\ \text { CHUBU } & 8 & 265264 & 0 & - \\ \quad \vdots & \vdots & \vdots & \vdots & \vdots \\ \quad & \vdots & \vdots & \vdots & \vdots \\ \text { ASXD } & 0 & - & 1 & 3469 \\ \text { COMEX } & 0 & - & 1 & 152 \\ \text { IPE } & 1 & 91389 & 0 & - \\ \text { KANEX } & 1 & 257189 & 0 & - \\ \text { SIMEX } & 1 & 64859 & 0 & - \\ \text { HEX } & 1 & 1378368 & 0 & - \\ \text { TOCOM } & 1 & 710774 & 0 & -\end{array}$

Abbreviations: $\mathrm{ASXD}=$ Australian Stock Exchange Derivatives, $\mathrm{BM} \& \mathrm{~F}=$ Bolsa $\mathrm{De}$ Mercoadorias \& Futuros, CBOT $=$ Chicago Board of Trade, CHUBU $=$ Commodity Exchange Nagoya, $\mathrm{CME}=$ Chicago Mercantile Exchange, $\mathrm{COMEX}=$ Division of New York Mercantile Exchange, CSCE = Coffee Sugar \& Cocoa Exchange, IPE = International Petroleum Exchange, KANEX = Kansei Agricultural Commodity Exchange, LIFFE $=$ London International Financial Futures Exchange, NYMEX $=$ New York Mercantile Exchange, SIMEX = Singapore International Monetary Exchange, HEX = Helsinki Exchanges, TOCOM =Tokyo Commodity Exchange.

An overview of introductions of exchange-listed commodity derivatives throughout the world is given in Table II. Because of space limitations, only the top seven and last seven exchanges are included. The exchanges have been classified according to the number of 
introductions over the period $1994-1998$. In this period a total of 140 new commodity derivatives were introduced. Twelve of these derivatives were de-listed within the period investigated. The London International Financial Futures \& Options Exchange and the Chicago Mercantile Exchange are the leaders in introductions with fifteen and fourteen respectively.

Measuring successful commodity derivative innovations is a complicated matter. The critical success levels for trading volume is necessarily arbitrary. A difficulty with volume data is that contracts for different commodities are not worth the same amount of money so that the economic significance of total volume across different contracts is unclear. Sandor (1973) used the cut-off point of 1,000 contracts traded annually to distinguish successful from unsuccessful contracts (Sandor, 1973). Silber (1981) applied more stringent criteria, choosing 10,000 or more contracts traded in the third year of a market's life as the measure of success. The Wall Street Journal's policy is to withhold a new market from listing in the price reporting section until it has established itself and demonstrated a fairly widespread acceptance among traders. A contract is listed if the daily trading volume exceeds 1,000 contracts.

Following Sandor's criteria, thirty one percent of the introductions in the period 19941998 failed. Following the more stringent criteria formulated by Silber, fifty eight percent of the introductions failed. 
The development and introduction of commodity derivatives is an expensive and timeconsuming process, especially when it concerns new derivatives. Amidst the turmoil of a risky market, stiff competition and many introduction failures, the commodity derivatives industry needs a conceptual model that incorporates all aspects relevant to the success and failure of commodity derivatives. In order to meet this need, a new and integrative approach towards commodity derivatives management is presented, which makes it easier to gain insight into the viability of new commodity derivatives before introduction, to assess and improve the viability of existing commodity derivatives and to provide the managers within the financial services industry with information about the tools they can use in the product development process of commodity derivatives. An integrated 'Marketing-Finance' approach (MF-approach) towards commodity derivatives management is proposed. The MF-approach proposes a development process of commodity derivatives in which the choice process and the wishes of potential customers (i.e. marketing aspects) are investigated simultaneously with the necessary technical properties which need to be met for trading to take place (i.e. finance aspects). In the MFapproach, both aspects supply each other with valuable information. Thus, the results from a customer analysis may generate information that can improve the specification of the derivative contract and afterwards test them in customer research. Conversely, one might use the results of the financial analysis to find out more specifically which customer characteristics are relevant for customer decision-making and use this information later to adjust the specifications and promotion of the commodity derivative. In such a sequence, customer research benefits from the results of the financial analysis and vice versa. The MF-approach can enhance commodity derivatives exchange 
management, brokerage houses and banks. It assists them in formulating concrete policy toward improving existing commodity derivatives and introducing new ones. This paper focuses only on the behavior of hedgers (those who want to manage price risk) and views the behavior of speculators (those who are willing to accept price risk) as being dependent on hedgers' actions (Working, 1953).

First, the finance approach and marketing approach are discussed, which form the basis of the conceptual model. Thereafter, the model, which integrates both approaches is presented.

\section{FINANCE APPROACH}

Financial management is concerned with the raising and allocation of financial funds. Norms for efficient financial management can be derived once the financial environment and the functioning of financial instruments have been understood (Merton, 1995). This approach to financial services such as the price risk management services of commodity derivatives markets will create the necessary conditions for success (Van Horne, 1986). The finance approach to price risk management services is therefore a normative one: what technical conditions will have to be fulfilled for a financial service to be successful? In the financial literature on commodity derivatives contracts, the commodity characteristics approach and the contract design approach can be distinguished.

The commodity characteristic approach defines feasible commodities for derivatives trading based on an extensive list of required commodity attributes. It focuses on the 
technical aspects of the underlying commodity. The following attributes are considered crucial for qualifying for the derivatives trade: 1) a commodity should be durable and it should be possible to store it; 2) units must be homogeneous; 3) the commodity must be subject to frequent price fluctuations with wide amplitude; supply and demand must be large; 4) supply must flow naturally to market and there must be breakdowns in an existing pattern of forward contracting.

The first attribute, durability and storability, has received considerable attention in commodity finance, since one of the economic functions often attributed to commodity derivatives markets is the temporal allocation of stocks. The commodity derivatives market is an integral part of this storage scenario because it provides a hedge against price risk for the carrier of stocks.

Since commodity derivatives contracts are standardized contracts, this approach requires the underlying product to be homogeneous, the second attribute, so that the underlying commodity as defined in the commodity derivatives contract corresponds with the commodity traded in the cash market. This allows for actual delivery in the commodity derivatives market.

The third attribute, a fluctuating price, is of great importance, since firms will feel little incentive to insure themselves against price risk if price changes are small. A broad cash market is important because a large supply of the commodity will make it difficult to 
establish dominance in the market place and a broad cash market will tend to provide for a continuous and orderly meeting of supply and demand forces.

The last crucial attribute, breakdowns in an existing pattern of forward trading, indicates that cash market risk will have to be present for a commodity derivatives market to come into existence. Should all parties decide to eliminate each and every price fluctuation by using cash forward contracts for example, a commodity derivatives market would be of little interest.

The commodity approach has received a lot of attention and has increased the insight into the factors determining viable commodity derivatives trade. However, the attributes considered necessary to this approach have proven themselves too strict to be useful as criteria for commodity derivatives market success. After all, different types of (exotic) commodity derivatives contracts have been developed that do not have (all of) the attributes mentioned above, but are successful anyway.

The contract design approach focuses on the contract specification (standardization process of the contract) as the critical factor determining the viability of a commodity derivatives market and hence on the technical aspects of the contract. A commodity derivative must reflect the commercial movement of a commodity both closely and broadly enough, so that price distortions will not be a result of specifications in the contract. To warrant hedging, the contract must be as close a substitute for the cash commodity as possible. Hedging effectiveness is an important determinant in explaining 
the success of commodity derivatives and as a result considerable attention has been paid to the hedging effectiveness of commodity derivatives.

There is a vast body of literature that takes the finance approach as outlined above to commodity derivatives markets. However, the fact that hedging not only lifts risks, but may also introduce risks of its own has, so far, only received limited attention. In fact, next to reducing risk, hedging on commodity derivatives markets also introduces risks that cannot be covered. Therefore, in attempting to understand the success or failure of commodity derivatives it is worthwhile analyzing, within the finance approach, the different sources of risk involved in hedging. The risks that originate from trading at commodity derivatives markets influence the commodity derivatives market's hedging effectiveness.

Recently Pennings and Meulenberg (1997) proposed a conceptual model for over-all risk reduction, from which they developed a measure for hedging effectiveness. Contrary to the existing measures, this one does not focus on portfolio performance, but on the hedging function of a futures contract. The measure takes into account the fact that futures contracts realize a reduction of price risk in the spot market while introducing a risk of their own. The measure discerns basic risk (i.e. the deviation in the spot-futures price relationship at the settlement date) and market-depth risk (i.e. is the risk the hedger faces from a sudden price decrease or increase due to order imbalances). Moreover, it takes into account the costs of commission. Let this measure be the distance between the hedging service offered by the futures exchange and the 'perfect hedge', an ideal situation 
where the hedging service eliminates risk in the spot market without introducing an additional risk of its own, then this distance can be subdivided into systematic and a nonsystematic elements. The systematic element, caused by the specifications of the futures contract and the structure of the futures exchange, can be managed by the futures exchange, whereas the non-systematic element is beyond the exchange's influence. The measure provides the hedger with a means of comparing the competitiveness of different futures contracts. It incorporates not only the characteristics of the futures contract, but also the spot market risks. The measure's futures market risk component indicates the hedging quality of the futures contract. The spot market price risk component emphasizes the need for price risk reduction.

Fulfilling the necessary conditions as proposed in the finance approach, however, does not guarantee the market success of the services provided by commodity derivatives. Their success also depends on the extent to which they succeed in meeting the needs of (potential) customers at a competitive price. The latter point of view stems from the marketing tradition, which holds that customers' needs occupy a central position in the development of products and services. 


\section{MARKETING APPROACH}

The marketing approach attempts to determine whether the hedging services provided by the commodity derivatives exchange satisfy potential customers' needs. Often, competing alternative products or services will be available to meet the firm's needs, which is why the marketing approach pays a lot of attention to the customer's decision-making process. Knowing how the customer reaches a decision and why he or she decides the way he or she does, gives the marketer clues on how to market the hedging service. Since customers are at the basis of any marketing operation, their needs constitute the starting point in marketing.

The total set of customer needs concerning commodity derivatives is differentiated into instrumental needs and convenience needs (see Figure 1). Customers will choose that "service-product" (futures, options, cash forwards, etc.) which best satisfy their needs, both instrumental and convenience, at an acceptable price. 


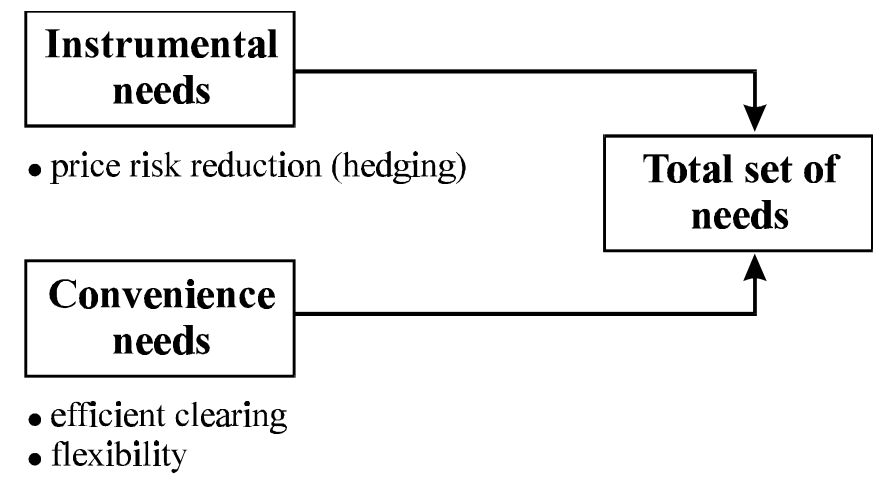

FIGURE 1

Total Set of Needs.

Instrumental needs are the hedgers' needs for price risk reduction. Hedgers wish to reduce, or, if possible, eliminate portfolio risks at low cost. The instrumental needs are related to the core service of the commodity derivatives market, which consists of reducing price variability to the customer. Not only do hedgers wish to reduce price risk, they also desire flexibility in doing business, easy access to the market, and an efficient clearing system. These needs are called convenience needs. They deal with the customer's need to be able to use the core service provided by the exchange with relative ease. The extent to which the commodity derivatives exchange is able to satisfy convenience needs determines the process quality. The service offering is not restricted to the core service, but has to be complemented by so-called peripheral services. The core plus peripheral services constitute the augmented service offering. An example of a commodity 
derivatives market's peripheral service is the efficient and correct conclusion of transactions.

The commodity derivatives market can meet both types of needs. In order to indicate which division of a commodity derivatives exchange is mainly responsible for satisfying instrumental needs and which for convenience needs, the commodity derivatives exchange can be divided into two identities, namely: the "floor" and the "clearing house". The "floor" is where the actual transactions take place. The word "floor" has been put between quotation marks, because commodity derivatives markets exist that technically no longer have a floor, the traditional trading place having been replaced with an electronic trading system. On the floor, the brokers execute customers' orders. Therefore, the floor can be seen as the place where mainly instrumental needs are being met. After all, the execution of an order means a hedge position has been taken in the commodity derivatives market, which reduces the customer's price risk. After the execution has taken place, the clearinghouse takes care of the financial settlement and, in the case of delivery, makes sure that the commodities delivered meet contract specifications. Therefore, the clearinghouse can be said to meet mainly the convenience needs.

After having analyzed the customer's needs, the marketing process will continue by designing the service and in developing the service delivery. Both the service design and the service delivery affect the nature of the customer's service experience (Parasuraman, Zeihaml and Berry, 1985). The service design is mainly linked to the instrumental needs whereas the service delivery is mainly linked to the convenience needs. The new Cantor 
Financial Futures Exchange, recently approved by the US Commodity Futures Exchange Commission (CFTC), is challenging the Chicago exchanges on service delivery. Because this exchange is an electronic market the accessibility of the "trading pit" is easier and the trading hours longer which makes this market more flexible compared to its competitors.

In most cases, more than one instrument will be available to meet the firm's needs for price risk reduction. This makes it interesting to know how the firm chooses between these alternatives. In order to gain insight into this, the firm's choice behavior concerning price risk management instruments must be investigated. Insight into the choice process provides the marketer with clues about the characteristics a commodity derivatives contract needs to possess in order to gain preference over the other alternatives.

Recent research from Pennings and Candel (1997) showed that the decision-making process of entrepreneurs of small and medium sized enterprises (SME's) for futures contracts appears to have a two-phase structure. During the first phase, entrepreneurs decide whether futures contracts constitute a relevant alternative and should be in their toolbox. In this phase important attributes were: the extent to which entrepreneurs feel that the use of futures will enhance their entrepreneurial freedom (as compared to other price risk management instruments), their understanding of the functioning of futures contracts (compared to their understanding of other relevant price risk management instruments) and the performance of futures contracts in the field of price risk reduction (compared to that of other relevant price risk management instruments). The entrepreneur compares the alternatives on the basis of different attributes. The entrepreneur's choice of 
any particular alternative depends on the importance the entrepreneur places on these attributes as well as on how the alternatives differ with respect to these attributes in the entrepreneur's evaluation. During the second phase of the decision making process, when futures contracts are already a part of the entrepreneur's toolbox, the difference between the entrepreneur's psychological reference price and the actual futures market price becomes an important factor in the decision for or against entering the futures market. The components entrepreneurial freedom and performance remain of importance during this phase of the decision process, whereas understanding no longer plays a part in the second phase. That is, after futures have been accepted as being part of the business of conduct and are in the toolbox of the entrepreneur, understanding does not play a major role in a concrete choice situation. These results have important managerial implications when developing and evaluating commodity derivatives. For example, the fact that entrepreneurial freedom is a dimension which the entrepreneur uses to evaluate different price risk management instruments, implies that positioning futures as an extra tool for entrepreneurs which allow them a degree of freedom in acting in the market place seems valuable. In order to reduce the psychological distance to futures contracts, the futures exchange might develop training programs for entrepreneurs allowing increasing their understanding of futures trading and making futures easy to use. The performance of futures can be increased by using a more appealing standardization procedure of the underlying commodity. Relaxing some of the standards may help increase the performance of futures. Recently, so-called flex-futures have been introduced for some commodities in the US. 
Insight into the choice process of firms and hence the attributes they use in order to compare alternatives provide the management of the commodity derivative exchange with a framework for improving service design (that is mainly the contract specification) and service delivery (that is mainly the clearing system). Moreover, insight into why firms choose the way they do provide valuable information for efficiently identifying certain target groups and customizing services. Because firms are confronted with alternatives during the choice process, the choice process may well bring latent needs to the surface. These are often convenience needs. This, in turn, influences service design and service delivery, if only indirectly.

Given the necessary conditions imposed by the finance approach, the results from the marketing approach may serve to make up the characteristics of a particular financial service. When creating a particular service, the marketing approach, in its preoccupation with customer needs, tends to pay only limited attention to issues of technical feasibility, whereas the finance approach tends to undervalue customer needs in favor of the technical aspects of a particular service. Therefore, the development of new commodity derivatives would be served by an integration of the marketing approach (with its stress on desirability from a customer perspective) and the finance approach (with its focus on the technical feasibility of a service). 


\section{THE MF-APPROACH}

While realizing that both the marketing approach and the finance approach to analyze the market for hedging services need further elaboration, commodity derivatives exchanges should use an integration of both approaches when developing and marketing hedging services.

The type of information used is characteristic for both approaches and therefore crucial in understanding the nature of the differences between the finance approach and the marketing approach. The finance approach makes use of technical information. Technical information consists of prices, rates of returns, volumes of transactions and historical data on all these items, at different locations and on different markets (see Figure 2). 


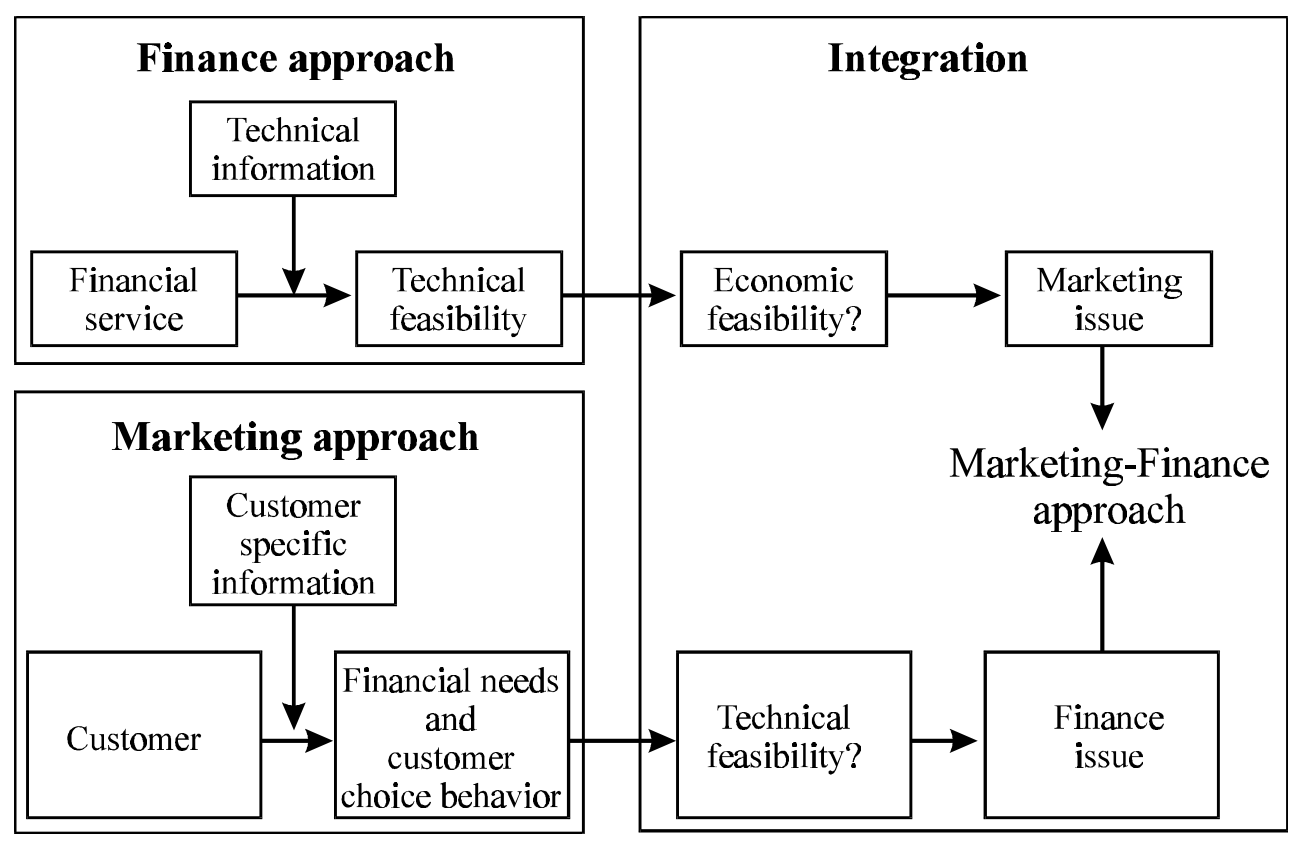

FIGURE 2

The Information Differences Between the Marketing and Finance Approach.

The marketing approach draws on customer-specific information. The latter type of information includes time preferences, choice criteria, investment opportunities, and the risk preferences of individual economic agents. Customer-specific information is essential for determining market needs and profit opportunities. A problem of financial institutions vis-à-vis customers may be information asymmetries, such as hidden information and hidden action, which might result in adverse selection and moral hazard. The cost of information asymmetry can be reduced by marketing research, if the expected value of perfect information is positive. Customer-specific information is also useful in selecting target markets. Targeting market segments and designing effective positioning 
strategies requires managers to have an insight into how the attributes of a serviceproduct are valued by current and prospective customers. Customer-specific information can provide that insight. Defining a commodity derivative from the point of view of customer needs might conflict with technical feasibility and vice versa.

It is often difficult to derive the successful functional and technical properties of financial services from the marketing approach alone. On the other hand, it remains unclear whether the feasible properties of financial services as determined in the financial approach generate sufficient demand. It seems, therefore, that the financial and marketing approach to financial services, whether from the perspective of supply- or demand side are complementary in developing, producing and marketing financial services. Does this complement guarantee the optimal contribution of a MF-approach or can it even better? It seems to us that further progress in the MF-approach could be made by truly integrating both approaches (see Figure 3). 


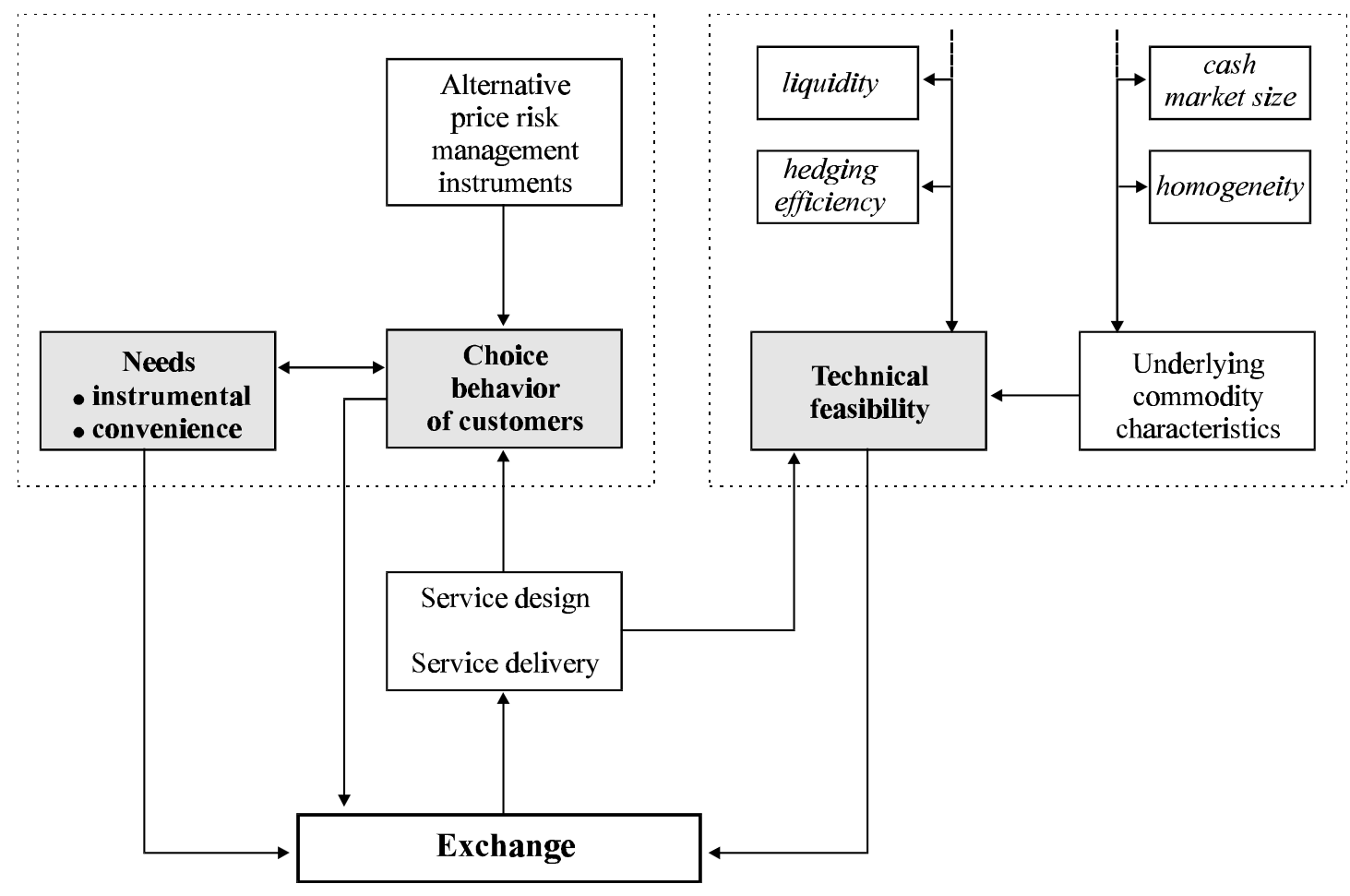

FIGURE 3

The MF-Approach.

Both approaches feed each other with information and provide feedback. Thus, the marketing approach will furnish information about the characteristics that make commodity derivatives contracts attractive to firms, whereas the finance approach will determine the technical feasibility of such commodity derivatives. This information, will then become the basis for a first concept of service design and service delivery. This concept will be adapted and improved after having tested it on target customers and financial experts. Then, the improved concept may, in turn, be improved by another round of testing and so on. Such a process towards commodity derivatives implies a full 
integration of the finance and marketing approach. The MF-approach is desirable to acquire insight into the necessary and sufficient conditions for successful commodity derivatives.

In order to benefit optimally from such integration, the finance approach needs a shift of perspective from portfolios to commodity derivatives exchange management. This means for example that the measures developed within the finance approach should also provide the exchange management with information on how to improve hedging efficiency. The marketing approach should focus particularly on a better understanding of the decisionmaking process of firms as far as the use of price risk management instruments is concerned. A better understanding of the "why do entrepreneurs decide the way they do?" is particularly important for the marketer.

The proposed MF-approach towards commodity derivatives management provides: 1) insight into the factors which play a role in the success of a commodity derivative, divided into two aspects namely factors with a financial character (referred to in this paper as the (finance approach') and factors dealing with the decision-making process of entrepreneurs with respect to hedging (referred to as the 'marketing approach'), and 2) a methodology for organizing the product development process of commodity derivatives, through the integration of both technical and marketing factors. Because the MFApproach contains all the relevant aspects it is a powerful tool for drawing conclusions about the viability of a commodity derivative. 


\section{ACKNOWLEDGEMENTS}

Financial support provided by the Amsterdam Exchanges (AEX), the Foundation for Research in Agricultural Derivatives and the Niels Stensen Foundation is gratefully acknowledged. The authors also express their thanks to the Board of Directors of the AEX and the management of the Warenterminbörse in Hanover (Hanover Commodity Exchange) for their generous participation in our research meetings. An earlier version of this paper was presented at the 1996 Chicago Board of Trade Futures Research Symposium, the 1997 Agrarökonomisches Colloquium (Finance Series) held at the University of Kiel, the 1997 Marketing Science Conference held at the University of California at Berkeley, the 1997 symposium of the Dutch National Business Administration Network held at the Rotterdam School of Management at the Erasmus University in Rotterdam, the 1997 Mansholt Institute Research Meetings, the 1997 MenM Colloquium held at the Wageningen University and Research Centre, and the 1998 SRAD Finance Research meeting held at the Amsterdam Exchanges. The authors express special thanks to C. Ennew, R.M. Leuthold, M.T.G. Meulenberg, J-B.E.M. Steenkamp, B. Wierenga and the faculty of the Office for Futures and Options Research at the University of Illinois at Urbana-Champaign which provided helpful comments on the research project and preliminary versions of this manuscript. 


\section{BIBLIOGRAPY}

Davey, E., and Maguire, F. (1996): “A Hell of a Year," Futures and Options World 297, $32-36$.

Merton, R.C. (1995): "Financial Innovation and the Management and Regulation of Financial Institutions," Journal of Banking and Finance, 19, 461-481.

Miller, M.H. (1990): “International Competitiveness of US Futures Exchanges,” Journal of Financial Services, 4, 387-408.

Parasuraman, A., Zeithaml, V.A., and Berry, L.L. (1985): “A Conceptual Model of Service Quality and its Implications for Future Research," Journal of Marketing, 49, 41-50.

Pennings, J.M.E., and Meulenberg, M.T.G. (1997): "Hedging Efficiency: A Futures Exchange Management Approach,” Journal of Futures Markets, 17, 599-615.

Pennings, J.M.E, and. Candel, M.J.J.M. (1997): "Modeling Choices of Small and Medium Sized Enterprises for Financial Services," Proceedings Marketing Science Conference in Berkeley, United-States, 21-24 March 1997.

Sandor, R.L. (1973): "Innovation by an Exchange: A Case study of the Development of the Plywood Futures Contract," Journal of Law and Economics, 16, 119-136.

Silber, W.L. (1981): "Innovation, Competition, and New Contract Design in Futures Markets," Journal of Futures Markets, 1, 123-155.

Sill, K. (1997): “The economic Benefits and Risks of Derivatives Securities," Business Review, Jan/Feb, 15-26.

Van Horne, J.C. (1986): Fundamentals of Financial Management. New Jersey: PrenticeHall International. 
Working, H. (1953): "Futures Trading and Hedging," American Economic Review, 43, 314-334. 